\title{
Hubungan Konsep Diri dengan Kenakalan Anak Jalanan pada Rumah Singgah Putra Mandiri Semarang
}

\author{
Agus Riyadi \\ UIN Walisongo Semarang, Jl. Walisongo 3-5 Semarang-Jawa Tengah, 50185 \\ e-mail: agusriyadi2011@gmail.com
}

\begin{abstract}
Adolescence is generally characterized by turbulent period in all areas and aspects of life and growth therefore closely associated with delinquency. This study aimed to determine the association of selfconcept and delinquency among the street children in the Shelter of Putra Mandiri Semarang. This study used the correlation design with product moment analysis. This study has confirmed there was a significant correlation between self-concept and delinquency among street children. The more positive self concept associated with positive behavior patterns, and if the self-concept was negative it would be increased negative behavior patterns. Thus the self-concept can be regarded as a control against various problems that occur on the streets that are more inclined towards juvenile delinquencies.
\end{abstract}

Keywords: street children, juvenile delinquency, self-concept

\begin{abstract}
Abstrak
Masa remaja merupakan rentangan usia yang diliputi oleh ketidakstabilan jiwa, masa penuh guncangan dalam pertumbuhan yang dilaluinya di segala bidang dan segi kehidupan oleh karena itu berkaitan erat dengan kenakalan. Penelitian ini bertujuan untuk mengetahui hubungan konsep diri dengan kenakalan anak jalanan pada Rumah Singgah Putra Mandiri Semarang. Penelitian ini menggunakan metode kuantitatif rancangan korelasional dengan analisis statistik product moment. Hasil temuan pada penelitian ini adalah sebagai berikut: ada korelasi yang signifikan antara konsep diri dengan kenakalan anak jalanan. Semakin positif konsep diri maka akan lahirlah pola perilaku yang positif pula, dan apabila semakin negatif konsep diri maka akan lahirlah pola perilaku yang negatif. Dengan demikian konsep diri bisa dikatakan sebagai pengendali individu dari berbagai penyimpangan-penyimpangan yang terjadi dalam dunia jalanan yang lebih cenderung ke arah kenakalan.
\end{abstract}

Kata Kunci: anak jalanan, kenakalan remaja, konsep diri

\section{Pendahuluan}

Istilah anak jalanan pertama kali diperkenalkan di Amerika Selatan tepatnya di Brazilia, dengan nama Meninos de Ruas untuk menyebut kelompok anak-anak yang hidup di jalan, dan tidak memiliki tali ikatan dengan keluarga (Bambang, 1993 : 9). Namun di beberapa tempat lainnya, istilah anak jalanan berbeda-beda, seperti Colombia mereka disebut Gamin (Urchin atau melarat) dan Ehinehes (kutu kasur), di Bolivia mereka disebut polillas (ngengat). Istilah-istilah tersebut sebenarnya menggambarkan bagaimana posisi anak-anak jalanan ini dalam masyarakat.

Permasalahan yang cukup memprihatinkan dalam kehidupan sehari-hari adalah perkelahian, penggunaan narkoba, pencurian dan prostitusi anak jalanan, dimana telah menarik anak-anak khususnya anak jalanan perempuan untuk ikut terlibat di dalamnya. Dalam hal ini, anak-anak jalanan itu disebut sebagai "anak yang di lacurkan." Penggunaan istilah ini adalah untuk menghindari istilah "pelacur anak" (child prostitutes) yang cenderung mengandung konotasi negatif (Odi, 2003: 90).

Salah satu upaya untuk mengatasi dampak tersebut terhadap kesejahteraan sosial anak pemerintah mengembangkan program pemberdayaan anak jalanan bekerja sama dengan Lembaga Swadara Masyarakat (LSM) melalui pendekatan Rumah Perlindungan Sosial Anak. Hal ini didasari karena anak sebagai generasi penerus adalah pewaris cita-cita perjuangan bangsa yang merupakan Sumber Daya 
Manusia (SDM) yang sangat penting dalam mencapai keberhasilan pembangunan untuk menjadi SDM yang berkualitas. Anak juga berhak atas peluang dan dukungan untuk mewujudkan dan mengembangkan diri dan kemampuannya.

Di sisi lain kesulitan anak jalanan untuk mewujudkan, mengembangkan diri dan kemampuannya menyebabkan banyak kebimbangan, kebingungan, kecemasan dan konflik baik konflik eksternal yang terbuka, maupun internal dalam batin sendiri yang tersembunyi dan tertutup sifatnya. Sebagai dampaknya anak lalu mengembangkan pola tingkah laku menyimpang dari norma-norma umum dengan cara berbuat semaunya sendiri demi keuntungan sendiri.

Oleh karena itu perlu adanya penerapan konsep diri yang kuat terhadap masing-masing individu karena secara kodrat manusia sejak lahir memiliki pembawaan untuk hidup bermasyarakat (Sudarsono, 2005: 106). Setiap orang pasti mempunyai konsep tertentu terhadap dirinya sendiri. Ada yang mempunyai konsep diri yang negatif dan ada pula yang positif. Konsep diri yang positif ataupun yang negatif dapat terbentuk oleh beberapa hal. Konsep diri positif dapat terbentuk oleh penanaman nilai-nilai agama yang kuat, kepercayaan diri, dan menerima diri sendiri. Sedangkan konsep diri negatif terbentuk oleh kurangnya perhatian, kasih sayang, kurangnya penanaman nilai-nilai agama, kurang kepercayaan diri, dan tidak mampu menerima diri apa adanya. Namun, satu hal yang paling menentukan adalah cara pandang seseorang terhadap dirinya sendiri. Semakin ia berpandangan negatif, semakin sering muncul konsep-konsep negatif tentang dirinya sendiri. Sebaliknya semakin ia mempunyai pandangan yang positif terhadap dirinya sendiri, semakin positif pula konsep diri yang ia miliki.

Segala persoalan dan problema yang terjadi pada remaja sebenarnya berkaitan dengan usia yang mereka lalui dan tidak dapat dilepaskan dari pengaruh lingkungan yang memegang peranan dalam kehidupan remaja, yaitu agama. Tapi sayang sekali dunia modern kurang menyadari betapa penting dan hebatnya pengaruh agama dalam kehidupan manusia, terutama pada orang-orang yang sedang mengalami keguncangan jiwa. Usia remaja terkenal dengan masa penuh guncangan dalam pertumbuhan yang dilaluinya di segala bidang dan segi kehidupan.

Masa remaja merupakan rentangan usia yang diliputi oleh ketidak stabilan jiwa anak, oleh karena itu berkaitan erat dengan juvenile delinquent (kenakalan remaja). Kaitan psikologis tersebut sejalan dengan kondisi lingkungan, akan tetapi yang kedua lebih dominan mendorong anak remaja menjadi delinquent. Kondisi lingkungan tersebut dapat bermula dari internal lingkungan keluarga, proses pendidikan di sekolah dan kelompok sosial, serta beberapa kondisi lain yang tidak menguntungkan perkembangan mental anak. Kaitan lain adalah pergaulan yang tidak sehat dengan teman-taman sebaya, pendidik, dan semua pihak yang terlibat dalam ikatan formal proses belajar mengajar sekolah, juga diperkuat oleh kondisi lingkungan yang tidak menguntungkan (Sudarsono, 2005: 37). Penelitian Haditono tahun 1997 menemukan bahwa motif melakukan tingkah laku nakal adalah mengikuti ajakan teman dan usaha mencapai keinginan (emosi yang tidak terkontrol), dan yang ketiga adalah mencari pelarian karena keadaan rumah yang tidak menyenangkan atau kurang kasih sayang (Haditono, 2004: 311).

Anak-anak nakal disebut pula sebagai pemuda-pemuda berandalan, pemuda aspalan atau anak muda jahat nakal. Pada umumnya pemuda-pemuda ini tidak memiliki kesadaran sosial dan kesadaran moral serta perilakunya didasarkan pada basis instingtif yang primitif. Karena fungsi kemauannya lemah, maka impuls-impuls, dorongan-dorongan dan emosinya jadi tidak terkendali, sehingga tingkah lakunya menjadi liar, agresif, dan destruktif 
(Kartono, 2002: 197). Bisa dikatakan individu seperti ini memiliki gangguan dalam "konsep diri" : bingung tentang jati dirinya dan kacau mengenai batas antara dirinya dan dunia sekitar, gangguan dalam kehendak tidak mampu menyelesaikan rangkaian tindakan yang diarahkan pada pencapaian tujuan tertentu (Supratiknya, 1995: 72).

Secara psikologis usia remaja merupakan umur yang dianggap "gawat" oleh karena yang bersangkutan sedang mencari identitasnya. Pertama-tama dia akan berpaling pada lingkungan terdekatnya, yakni orang tua, saudarasaudaranya, dan mungkin juga kerabat dekatnya. Apabila idealismenya tidak terpenuhi oleh lingkungan terdekatnya, maka dia akan berpaling kepada lingkungan lain. Oleh karena itu, lingkungan terdekat harus senantiasa siap untuk membantu sang remaja. Remaja lebih banyak memerlukan pengertian daripada sekedar pengetahuan saja, dia harus mengerti mengapa manusia tidak boleh terlalu bebas dan juga tidak boleh terlalu terikat (disiplin). Memang orang tua kadang-kadang terlalu mementingkan disiplin atau keterikatan daripada kebebasan, sedangkan remaja lebih memilih kebebasan daripada disiplin atau keterikatan. Namun manusia memerlukan keduanya dalam keadaan yang serasi, manusia yang terlalu disiplin hanya akan menjadi "robot" yang mati daya kreatifitasnya, sedangkan manusia yang terlalu bebas akan menjadi makhluk lain (yang bukan manusia).

Mereka yang lebih memilih kebe-basan dari pada disiplin atau keterikatan, beranggapan bahwa dunia jalanan lebih menjanjikan, karena tanpa ada for-malitas serta keterikatan yang mengatur mereka. Hal inilah yang menjadi suatu permasalahan, karena mereka tidak memiliki kesadaran sosial dan kesadaran moral sehingga mereka akan bertindak semau sendiri tanpa ada batasan-batasan yang mengikat mereka.
Fenomena anak jalanan yang sering ditemui pada kota-kota besar menggambarkan betapa banyaknya orang tua yang tidak mampu memenuhi kewajiban dan tanggung jawab yang dibebankan kepadanya. Oleh karena itu umat Islam berkewajiban mengentaskan anak jalanan dari pandangan masyarakat yang menilai bahwa anak jalanan itu sangat negatif. Kehadiran mereka dianggap mengganggu ketertiban dan keamanan orang lain, membahayakan diri sendiri, tindak kriminalitas dan kesan kurang baik terhadap citra bangsa.

Sebagian anak jalanan yang berada di Semarang tinggal di jalan. Di kawasan Pasar Johar, anak biasanya beristirahat dan tidur di los-los pasar dan masjid. Sedangkan di kawasan Tugu Muda, tempat-tempat yang dijadikan istirahat dan tidur mereka yaitu di taman Tugu Muda, beberapa gedung kosong seperti Lawang Sewu, Los Pasar Bulu, dan Gedung Gris.

Tindakan mereka yang tanpa kontrol sering meresahkan masyarakat setempat, seperti: mencuri, berjudi, mabuk-mabukan, bahkan penyimpangan seksual yang dilakukan sesama anak jalanan. Hal ini cenderung disebabkan karena pengaruh teman sebaya serta lingkungan di mana dia bertahan hidup. Bisa dikatakan mereka memiliki gangguan dalam konsep dirinya, sehingga berdampak pada ketidakstabilan kondisi kejiwaan mereka. Hal inilah yang menyebabkan anak jalanan tidak bisa mengendalikan emosinya, sehingga mudah terpengaruh oleh lingkungan sekitar yang menyebabkan mereka berperilaku nakal.

Oleh karena itu anak jalanan tidak bisa dibiarkan begitu saja, karena ber-pengaruh terhadap perkembangan kehidup-an anak untuk mencapai masa depannya. Oleh karena itu diperlukan adanya dakwah yang efektif dalam menangani permasalah-an ini, yaitu dakwah yang dilakukan me-lalui bimbingan konseling Islam, baik itu di lembaga-lembaga sosial maupun rumah singgah. Sebab dikawatirkan anak jalanan tanpa adanya dasar pendidikan agama akan menjadi generasi yang lemah. 
Rumah Singgah Putra Mandiri Semarang merupakan tahap awal bagi seorang anak, khususnya terhadap anak jalanan untuk memperoleh pelayanan selanjutnya. Oleh karenanya penting untuk menciptakan suasana yang aman, menarik, dan menyenangkan bagi anak jalanan. Dengan upaya bimbingan Islam diharapkan mampu memberikan hasil yang positif yang sesuai dengan karakter anak jalanan itu sendiri. Apabila kepribadiannya dipenuhi oleh nilai-nilai agama, maka akan terhindarlah dia dari kelakuan-kelakuan yang tidak baik (Daradjat, 1983: 114-115). Rumah Singgah Putra Mandiri Semarang merupakan rumah perlindungan sosial anak yang memberikan program pembinaan dan pengawasan terhadap anak jalanan sebagai ganti bimbingan dari orang tua. Penanaman pendidikan keagamaan kepada anak jalanan akan membentuk jiwa dan pribadi yang baik, berbudi dan taat kepada perintah agama sehingga tidak akan keluar menjadi pribadi yang jahat bahkan menjadi penyakit masyarakat. Program rumah perlindungan sosial anak dalam pendidikan keagamaan dapat dijadikan usaha untuk mengembalikan kembali anak jalanan seperti keadaan dulu di keluarganya walau tanpa orang tua. Atau dengan kata lain menjadikan anak jalanan sebagai pribadi yang mandiri dengan dilandasi budi pekerti dan agama yang kuat.

Fenomena anak jalanan sebagaimana di atas juga menjadi salah satu objek aktualisasi dakwah Islam, yang menuntut umat Islam ikut mencari jalan keluar atas persoalan tersebut. Melalui program bimbingan yang ada di Rumah Singgah Putra Mandiri Semarang diharapkan mampu memberikan pemahaman yang lebih komprehensif terhadap perilaku psikologis anak jalanan, dengan melalui proses bimbingan yang terprogram dengan baik, maka diharapkan akan mampu memudahkan dalam peningkatan konsep diri anak jalanan sebagai pengontrol terhadap perilaku kenakalan anak jalanan yang dalam hal ini akan dipecahkan lewat penelitian tentang hubungan antara konsep diri dengan perilaku anak jalanan.

\section{Metode Penelitian}

Penelitian ini merupakan jenis penelitian kuantitatif. Dikatakan kuantitatif karena data yang diperoleh nantinya berupa angka (Arikunto, 1998: 10). Dari angka yang diperoleh akan dianalisis lebih lanjut dalam analisis data. Untuk mendapatkan data yang berkaitan dengan penelitian, peneliti menggunakan angket atau instrumen yang disusun berdasarkan variabel yang diteliti.

Setelah data terkumpul maka langkahlangkah selanjutnya adalah menganalisa data tersebut. Dalam analisis ini penulis menggunakan teknik analisa data statistik.

Untuk mengetahui keadaan psikologis subjek terlebih dahulu peneliti akan melakukan uji coba terhadap angket yang telah disusun. Uji coba dilakukan kepada 20 orang subjek dengan meng-gunakan cara acak. Hal ini dilakukan untuk mengetahui nilai validitas dan reliabilities angket tersebut.

Adapun item dari sebaran angket dapat dilihat dari Tabel 1. Sementara itu, sebaran angket kenakalan anak jalanan juga mempergunakan 40 item yang dijabarkan dari 5 indikator yang dapat dilihat dalam Tabel 2.

Pengukuran kedua skala tersebut mengikuti skala Linkert (Nazir, 1988: 398) dengan mempergunakan lima alternatif jawaban : sangat sesuai (SS), sesuai (S), netral (N), tidak sesuai (TS), sangat tidak sesuai (STS). Skor jawaban mempunyai nilai alternatif 1 sampai 5 . 
Tabel 1

Spesifikasi Angket Konsep Diri

\begin{tabular}{clccc}
\hline No & Dimensi & Favorable & Unfavorable & Jumlah \\
\hline 1 & Kepercayaan diri & $1-5$ & $6-10$ & 10 \\
2 & Tanggung jawab & $11-15$ & $16-20$ & 10 \\
3 & Konsekuensi & $21-25$ & $26-30$ & 10 \\
4 & Cita-cita & $31-35$ & $36-40$ & 10 \\
& Jumlah & 20 & 20 & 40 \\
\hline
\end{tabular}

Tabel 2

Spesifikasi Angket Kenakalan Anak Jalanan

\begin{tabular}{llccc}
\hline No & Dimensi & Favorable & Unfavorable & Jumlah \\
\hline 1 & Perkelahian & $1-5$ & $6-10$ & 10 \\
2 & Pencurian & $11-15$ & $16-20$ & 10 \\
3 & Ketergantungan alkohol & $21-25$ & $26-30$ & 10 \\
4 & Seks bebas & $31-35$ & $36-40$ & 10 \\
& Jumlah & 20 & 20 & 40 \\
\hline
\end{tabular}

Nilai yang diberikan pada masingmasing alternatif jawaban adalah sebagai berikut : untuk item favorable sangat sesuai (SS) memperoleh nilai 5, sesuai (S) memperoleh nilai 4 , netral $(\mathrm{N})$ memperoleh nilai 3, tidak sesuai (TS) memperoleh nilai 2, dan sangat tidak sesuai (STS) memperoleh nilai 1 .

Sedangkan untuk jawaban item unfavorable sangat sesuai (SS) memperoleh nilai 1, sesuai (S) memperoleh nilai 2, netral $(\mathrm{N})$ memperoleh nilai 3, tidak sesuai (TS) memperoleh nilai 4, sangat tidak sesuai (STS) memperoleh nilai 5.

Analisis yang digunakan untuk menguji kebenaran hipotesis yang diajukan adalah melalui pengolahan data yang akan mencari hubungan antara variabel $(\mathrm{X})$ dan variabel (Y) yang dicari melalui rumus korelasi "product moment".

Variabel pengaruh (independent) dalam penelitian ini adalah konsep diri dengan indikator : kepercayaan diri, tanggung jawab, konsekuensi, cita-cita. Sedangkan variabel terpengaruh (dependen) dalam penelitian ini adalah kenakalan anak jalanan dengan indikator: perkelahian, pencurian, ketergantungan alkohol, dan seks bebas.

Dalam analisis ini penulis mengadakan perhitungan-perhitungan lebih lanjut melalui tabel distribusi frekuensi yang ada, dari hasil analisis pendahuluan.

Selanjutnya dimasukkan rumus korelasi "product moment" yaitu :

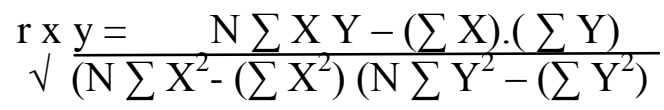

keterangan :

r x y : Indek angka korelasi product moment antara X dan Y

$\mathrm{X}$ : Nilai variabel $\mathrm{X}$

$\mathrm{Y}$ : Nilai variabel $\mathrm{Y}$

$\mathrm{XY}$ : Jumlah perkalian antara $\mathrm{X}$ dan $\mathrm{Y}$

$\mathrm{X}^{2}$ : Kuadrat nilai $\mathrm{X}$

$\mathrm{Y}^{2}$ : Kuadrat nilai $\mathrm{Y}$

$\Sigma \mathrm{XY}$ : Jumlah perkalian antara $\mathrm{X}$ dan $\mathrm{Y}$

$\mathrm{N}$ : Jumlah responden

Dalam analisis lanjut sekaligus untuk membuat interpretasi lebih lanjut dengan membandingkan harga $r$ tabel dengan $r$ yang diteliti dengan kemungkinan;

Jika $\mathrm{r}$ tabel (level 1\% atau 5\%) lebih kecil dari $\mathrm{r}$ hasil maka nilai menunjukkan signifikan ( hipotesis $(\mathrm{Ht})$ diterima).

Jika $r$ tabel ( level 1\% atau 5\%) lebih besar dari $\mathrm{r}$ hasil maka nilai menunjukkan non signifikan ( Ho ditolak ) 
Analisis uji hipotesis pada tahap ini penulis melakukan tes koefisien dengan hipotesis nihil (Ho) karena tidak signifikan pada taraf $1 \%$ atau $5 \%$ sehingga hipotesis ditolak.

Selanjutnya dari hasil olahan data, akan dianalisis lebih lanjut dengan mempergunakan metode deskriptif analisis. Prosedur metode ini merupakan prosedur pemecahan masalah yang diteliti dengan menggambarkan keadaan objek yang sebenarnya dan sesuai dengan fakta yang nampak, dalam hal ini tidak hanya berupa penyajian data secara deskriptif, melainkan data yang telah terkumpul diolah dan ditafsirkan (Nawawi, dkk, 1996: 73).

Analisis akhirnya meng-interpretasikan hasil analisis kuantitatif, faktor dominan yang mempengaruhi dan yang dipengaruhi serta kesimpulan, apakah hipotesis yang diajukan dapat dinyatakan benar atau salah.

\section{Hasil dan Pembahasan}

Hasil utama penelitian menunjukkan bahwa ada hubungan signifikan antara konsep diri dengan kenakalan anak jalanan pada Rumah Singgah Putra Mandiri Semarang. Semakin tinggi konsep diri maka akan semakin rendah kenakalannya. Dengan demikian konsep diri dapat dikatakan sebagai faktor pengontrol diri sendiri terhadap perilaku kenakalan anak jalanan.

Anak jalanan yang memiliki konsep diri yang positif akan mampu memandang, memahami, dan mengerti dirinya sendiri, baik yang berupa kelebihan maupun kekurangan, mereka mampu mengembalikan fitrah yang ada pada dirinya, sedangkan anak jalanan yang memiliki konsep diri yang negatif tidak akan mampu memandang, memahami, dan mengerti dirinya sendiri, bahkan cenderung mudah terpengaruh oleh teman sebayanya. Anak jalanan harus mempunyai konsep diri yang positif supaya dapat membentengi dirinya agar terhindar dari perilaku yang bertentangan dengan norma agama dan norma sosial. Karena ketaatan dan kepatuhan individu dalam menjalankan ajaran agama dan norma sosial ditunjang dari ciriciri yang melekat pada individu yang memiliki konsep diri yang positif.

Anak-anak merupakan tumpuan harapan agama dan negara, yang keberadaannya diharapkan menjadi penerus serta mempunyai nilai lebih pada keimanan dan intelektualitasnya terutama pada konsep dirinya. Karena terdapat potensi jasmani, rohani, dan akal budi dalam diri mereka yang harus dikembangkan agar mampu menghadapi tantangan zaman yang semakin komplek dan berat. Manusia yang menyadari bahwa dirinya memiliki dua dimensi yang saling berinteraksi yaitu jasad dan ruh, akan mendapati bahwa banyak motivasi diri yang mereka miliki untuk berkembang dan untuk berbuat lebih banyak lagi dalam kehidupannya. Menempatkan dua posisi yang berbeda ini dalam satu cita pencapaian yang paripurna, adalah bagian terpenting mengapa manusia memiliki keutamaan bila dibandingkan dengan makhluk lainnya.

Asumsi ini didasarkan atas pertimbangan bahwa seseorang yang memiliki konsep diri yang positif akan selalu memandang positif kehidupan ini, sehingga individu akan berusaha semaksimal mungkin untuk mencapai apa yang diinginkannya, dengan mengembangkan potensi yang ada pada dirinya. Tujuan utama dari kehidupan individu sama dengan tujuan dakwah yaitu mencapai kebahagiaan hidup di dunia dan akhirat. Dan untuk mencapai tujuan tersebut, tentunya individu akan menjauhkan diri dari berbagai bentuk pelanggaran dan penyimpangan terhadap ajaran agama dan norma-norma yang berlaku di dalam masyarakat.

Orang yang memandang positif dirinya cenderung menaati norma-norma yang ada dan semaksimal mungkin meng-hindari perbuatan-perbuatan yang ber-tentangan dengan aturan tersebut dan kemudian individu akan meningkatkan kembali 
fitrahnya, bertawakkal, dan me-nyadari kelebihan dan kekurangan yang dimilikinya.

Sebagaimana diungkapkan oleh Faqih (2001: 37), individu yang mampu mengetahui, memahami, mengerti, dan mengenal dirinya sendiri akan dengan mudah mengembangkan potensi yang dimilikinya sebagai beragama, sosial, individu, dan berbudaya, sehingga akan lebih mudah mencegah timbulnya masalah, memecahkan masalah, dan menjaga berbagai kemungkinan timbulnya masalah, selanjutnya akan membuat individu tersebut bertawakkal atau berserah diri kepada allah SWT.

Sementara itu, Islam memandang bahwa sejak kecil seorang anak harus dibiasakan mengenal ajaran agama sebagai pedoman dasar bagi kehidupannya kemudian, ajaran agama tidak saja berisikan ubaidiyah, melainkan juga aspek hubungan kemanusiaan dan kehidupan yang lain (Faqih, 2001: 76). Untuk itulah, ekspresi jati diri anak jalanan yang berada di masa transisi ini, ditambah oleh kondisi dunia modern yang mengidap penyakit spiritual dan emosional ini, memerlukan pendampingan, kontrol, dan bahkan advokasi. Di sini, peranan orang tua, pendidik, tokoh masyarakat, hingga satuan-satuan kecil keluarga, dan komunitas sosialnya akan sangat memberikan warna ekspresi jati diri tersebut. Dengan diiringi ketaatan yang tinggi pada diri anak jalanan yang memiliki konsep diri positif akan menghantarkannya kepada pencapaian kemampuan mewujudkan kebahagiaan hidup di dunia dan akhirat.

Islam menganut suatu paham bahwa manusia itu pada dasarnya adalah bersih (fitrah) seperti kertas putih, kemudian akan berubah karena pengaruh lingkungan, sebagaimana sabda Nabi yang berbunyi: "setiap anak dilahirkan di atas fitrahnya maka orang tua yang mendidiknya menjadikannya beragama yahudi atau nasrani atau majusi” (Jumantoro, 2001: 6).
Dengan demikian manusia itu mempunyai potensi yang sama untuk berbuat kotor ataupun bersih, berbuat ma'ruf ataupun munkar tergantung dominasi rangsangan yang diterimanya, sehingga manusia juga di sebut human condition, artinya lingkungan di mana dia hidup tidaklah hanya sekedar pelengkap saja melainkan lingkungan itu memberikan warna atau corak tertentu dalam membentuk karakter seseorang (Jumantoro, 2001: 8-9). Sebagaimana Nabi bersabda yang artinya: "manusia diciptakan lurus (berpegang teguh pada ajaran agama), kemudian setan membengkokkannya".

Jelaslah bahwa kenakalan anak jalanan bukanlah suatu atau keadaan yang berdiri sendiri tetapi merupakan perpaduan dari beberapa kondisi yang di alami anak-anak jalanan. Jika dalam pertumbuhan dan perkembangan anak kurang mendapat pendidikan dan pengarahan yang penuh tanggung jawab dari kedua orang tua mereka, maka kenakalan anak jalanan merupakan akibat yang tidak bisa dihindarkan lagi.

Keluarga dan lingkungan tempat tinggal merupakan dua wilayah terdekat dari anak yang memiliki pengaruh yang signifikan dalam perkembangannya sebagai manusia. Dalam keluarga dan lingkungan tempat tinggal, terdapat fungsi dan nilainilai tertentu yang di anut, yang merupakan bagian dari konstruksi sosial yang berlaku di wilayah atau komunitas tertentu.

Dengan demikian, seorang anak tidak pernah hidup dan tumbuh dalam ruang "vakum nilai dan fungsi", melainkan dalam udara nilai dan fungsi yang menafasi kehidupan keluarga dan masyarakat sekitarnya. Keluarga menjalankan peran tertentu terhadap anak dan mengajarkan nilai sosial dan budaya yang berlaku dalam masyarakatnya. Agar kehadiran anak dapat diterima di lingkungan di mana mereka tinggal masyarakat mengembangkan nilai sosial-budaya tertentu sebagai alat untuk menjalankan fungsinya, dan menjadikan 
nilai sosial-budaya tersebut sebagai rambu komunitas yang tinggal di dalamnya guna menjalankan perilaku tertentu (Dewi, 2003: 22).

Asumsi awal yang dimiliki masyarakat bahwa kemiskinan merupakan faktor klise yang muncul hampir pada setiap permasalahan sosial yang ada di masyarakat. Dari kemiskinan muncul beberapa problem sosial bagai "efek domino" di mana satu faktor akan mempengaruhi faktor yang lain dan seterusnya. Dari kemiskinan akan menimbulkan pendidikan rendah dan kurangnya gizi anak, sehingga anak akan putus sekolah dan masuk ke dunia jalanan dan menjadi nakal (Dewi, 2003: 41).

Asumsi yang di miliki masyarakat bahwa penyebab kenakalan anak adalah kemiskinan tidak terbukti sepenuhnya benar. Banyak faktor lainnya yang ditemukan selama proses penelitian yang sifatnya umum maupun khusus, bergantung wilayah dan keadaan anak. Di mana satu faktor dengan faktor yang lainnya saling berkaitan bahkan saling mempengaruhi. Masing-masing faktor penyebab pun dapat saling memperkuat untuk mendorong anak menjadi nakal. Beberapa faktor penyebab dominan yang ditemukan dalam penggalian data di lapangan antara lain : keluarga, lingkungan, dan dorongan dari diri anak sendiri.

Dari berbagai faktor dominan penyebab kenakalan anak jalanan tersebut, untuk itu diperlukan suatu upaya yang dapat mengarahkan anak jalanan kepada perkembangan hidup yang serasi dan harmonis. Salah satu upaya tersebut dapat berupa layanan atau bimbingan yang dapat membentengi diri dari semua yang merugikan. Anak jalanan merupakan generasi penerus bangsa seperti yang lainnya, sebagai generasi penerus bangsa, mereka memerlukan pembinaan dan bimbingan supaya mereka menjadi manusia yang bertanggung jawab, tangguh dan berbudi luhur, memiliki konsep diri yang kuat. Pembinaan dan bimbingan yang di berikan kepada mereka banyak sekali jalannya, di antaranya dengan memasukkannya pada lembaga-lembaga yang memang didirikan untuk pembinaan mental dan pembinaan masa depan anakanak. Lembaga-lembaga yang dimaksud antara lain, lembaga sosial, rumah singgah, pondok pesantren, dan lain-lain. Rumah Singgah Putra Mandiri Semarang merupakan salah satu tempat yang diperuntukkan bagi anak-anak yang kurang beruntung, khususnya anak jalanan. Di sini anak jalanan mendapatkan perlindungan, pemulihan, rehabilitasi bagi anak yang membutuhkan perlindungan khusus agar anak dapat tumbuh kembang secara wajar.

Menurut pemahaman penulis, Rumah Singgah Putra Mandiri Semarang merupakan tempat di mana anak mendapatkan pelayanan melalui model protection, sebagai tempat berlindung anak dari tindak kekerasan, model kuratif rehabilitatif, sebagai upaya mengatasi permasalahan anak dengan membetulkan sikap dan perilakunya yang nakal, model asertif, yaitu melatih anak jalanan agar bisa bersikap tegas dan tidak membiarkan dirinya diatur dan dikendalikan oleh naluri dan lingkungan, tetapi harus dapat mengendalikan perilakunya dengan ratio, akal sehat, dan suara hati. Selanjutnya, untuk membantu memberikan bimbingan kepada anak jalanan (client) diperlukan pengasuh (konselor) yang mempunyai karisma, keunikan, sederhana dan tidak sombong, menguasai metodologi yang efektif serta memahami kondisi serta psikis dari anak jalanan.

Konselor dapat mengajak klien untuk mengadakan pemikiran yang mendalam tentang dirinya sendiri terutama yang berkaitan dengan hakikat dirinya dan tujuan dari hidupnya, konselor mengajak klien berdialog/tukar pikiran, membantu client untuk mampu mengenali jati dirinya sebagai makhluk spiritual yang sekaligus sebagai makhluk sosial, konselor membantu klien untuk mampu berfikir positif dan menghilangkan pikiran/sudut pandang yang negatif yang dapat menjerumuskan 
pada tindakan merugikan dan klien juga dapat dibantu untuk dapat mencari dan menemukan jawaban atas pertanyaan yang mendasar, seperti untuk apa ia hidup di dunia? Mau kemana hidupnya? Apa tujuan hidup yang sedang dijalaninya? Apakah hidupnya sudah benar? Dan lain-lain yang dapat membantu klien menjadi lebih cerdas secara spiritual atau menemukan makna hidupnya serta lebih mengenal konsep dirinya. Dengan demikian maka klien akan mampu mengangkat dirinya sendiri dari keterpurukan, ketidakberdayaan, dan keputusasaan.

Sejak awal dijelaskan bahwa asal kejadian manusia telah diciptakan membawa fitrah (potensi) cenderung kepada kebenaran dan manusia tidak bisa menghindar dari fitrah itu. meskipun boleh jadi manusia mengabaikan atau tidak mengakuinya. Dan pada dasarnya setiap tindakan dan perilaku manusia dipengaruhi oleh fitrah kemanusiaannya. Dengan bertindak sesuai dengan fitrah maka seseorang akan memiliki kejujuran, kebijaksanaan, visioner, tabah (berani mengambil resiko), akhlak terpuji, memiliki prinsip (iman) yang teguh, bertanggung jawab (taqwa) yang mampu memberikan hasil yang berupa amal shaleh sehingga hidupnya akan penuh nilai dan makna. Dengan kata lain, orang yang memiliki kesadaran fitrah adalah orang yang memiliki konsep diri yang positif.

Rumah Singgah Putra Mandiri Semarang merupakan tahap awal bagi anak jalanan untuk memperoleh pelayanan selanjutnya, dalam mengembalikan harga diri, kepercayaan diri serta mengembalikan kemampuan menjalankan fungsi sosial di masyarakat, sehingga mereka mampu memupuk kesadaran dan tanggung jawab sosial. Oleh karenanya penting untuk menciptakan suasana aman, penuh kasih sayang dan menyenangkan dalam Rumah Singgah Putra Mandiri Semarang sehingga mereka merasa diperhatikan. Dalam hal ini mereka akan lebih mudah dalam mengaktualisasikan diri (berkarya, berprestasi, dan mengembangkan potensi /bakat) tetapi masih di bimbing dan di beri tahu kekurangan serta kesalahannya.

Maslow dan Rogers mengatakan bahwa aktualisasi diri adalah apabila seseorang menggunakan semua bakatnya untuk menjadi apa yang ia mampu menjadi, mengaktualisasikan atau mewujudkan potensinya. Menurut Maslow, aktualisasi diri merupakan karakteristik yang fundamental, suatu potensialitas yang ada pada semua manusia saat dilahirkan, tetapi yang sulit hilang, terhambat atau terpendam dalam proses "pembudayaan". Rogers menekankan bahwa sumber kreatifitas adalah kecenderungan untuk mengaktualisasikan diri, mewujudkan potensi, dan dorongan untuk berkembang dan menjadi matang (Tasmara, 2002: 167-168).

Seorang muslim harus mempunyai konsep diri yang mencakup citra diri dan harga diri serta kebermaknaan hidup. Sebagai seorang muslim, seharusnya tersentuh jiwanya oleh makna dari Islam itu sendiri, yaitu istislam "sikap berserah diri" yang membawa kedamaian kesejahteraan (as-salam), dan dilandasi jiwa yang ikhlas (sincerity). Masalahnya, sejauh ke-Islaman yang diyakini tersebut membentuk semacam konsep diri dan kemudian dibawa dalam lapangan kehidupan yang nyata. Maka posisi muslim dihadapan Allah dan alam adalah selalu bersikap dan berpihak pada kedamaian harmoni dan menjauhkan diri dari berbagai perbuatan yang akan merusak (fasad) (Tasmara, 2002: 204).

Dapat disimpulkan bahwa hubungan konsep diri dengan kenakalan memiliki peranan penting. Dengan memiliki konsep diri yang positif, anak jalanan akan mampu menghargai dirinya sendiri secara wajar, optimis, penuh percaya diri, bersikap positif, melihat hal-hal positif yang dapat dilakukan demi keberhasilan di masa mendatang. Sebaliknya, anak jalanan yang memiliki konsep diri yang negatif, mereka cenderung bersikap pesimistik terhadap kehidupan, mudah menyerah, dan suka menyalahkan diri sendiri. Akibatnya, bila 
mereka telah meyakini dan memandang bahwa dirinya lemah tidak berdaya, tidak disukai, tidak kompeten, merasa selalu gagal, malang, kehilangan daya tarik terhadap hidup, mereka cenderung berbuat hal-hal yang tidak diinginkan dan bertentangan dengan nilai-nilai yang berlaku di dalam masyarakat, karena telah terpengaruh oleh teman-teman sebayanya.

Kecenderungan berperilaku delinquent (kenakalan) akan sangat nampak ketika berbagai persoalan hidup mengisi pikiran dan perasaan anak jalanan, dan stereotipe budaya mengharuskan mereka tumbuh dewasa seperti apa yang di-harapkan masyarakat, di saat yang sama pula konsepsi diri mulai turun, mereka menjadi gelisah dan timbul suatu dilema yang menyebabkan krisis identitas.

Sebagian anak jalanan kurang mampu menangani masalah krisis identitas yang dialaminya. Sehingga mereka memerlukan kepercayaan dan optimisme untuk menumbuhkan kembali identitas diri dan integritas dirinya selain itu juga mereka memerlukan penanganan hidup yang akan mampu mengarahkan, mengatur dan mengontrol kenakalan anak jalanan, salah satunya adalah penanaman moral keagamaan. Dengan demikian anak lebih dapat bersikap optimis dalam memandang setiap tantangan, kegagalan tidak akan di pandang sebagai kematian melainkan sebagai pelajaran berharga dalam melangkah kehari depan.

Allah mengaruniakan pada manusia kemampuan-kemampuan berkembang dalam dirinya. Kemampuan-kemampuan manusia itu ada yang bersifat native (dasar), dan ada pula yang bersifat acquired atau proses belajar. Kemampuan itu memungkinkan kepada manusia untuk mengembangkan potensi yang ada untuk menghadapi problem-problem dalam dunia sekaligus merefleksikan fungsi dirinya sebagai "Kholifah al Allah Fil ardli" (Kholifah Allah di Bumi) (Jumantoro, 2001: 126).
Akhirnya dari uraian di atas dapat di cermati bahwa sudah menjadi kewajiban pengasuh (konselor) Rumah Singgah Putra Mandiri Semarang untuk membimbing dan mengarahkan anak-anak jalanan dengan tingkah laku yang lebih baik dari sebelumnya, serta membina dan mendidik anak jalanan, agar mereka dapat mengembangkan potensi dirinya seoptimal mungkin dan sekaligus untuk mencegah berbagai kendala atau faktor-faktor yang mungkin akan mengkontaminasi (meracuni) perkembangan anak, sehingga tidak memungkinkannya menjadi sebab timbulnya masalah baru.

\section{Simpulan dan Saran}

Berdasarkan hasil temuan pada penelitian, maka dapat ditarik kesimpulan sebagai berikut : ada korelasi negatif yang signifikan antara konsep diri dengan kenakalan anak jalanan, khususnya di Rumah Singgah Putra Mandiri Semarang. Semakin positif konsep diri maka akan lahirlah pola perilaku yang positif pula, dan apabila semakin negatif konsep diri maka akan lahirlah pola perilaku yang negatif. Dengan demikian konsep diri bisa dikatakan sebagai pengendali terhadap individu dari berbagai penyimpanganpenyimpangan yang terjadi dalam dunia jalanan yang lebih cenderung ke arah delinquent.

Hasil yang telah diperoleh dari penelitian ini, tidak lepas dari beberapa keterbatasan, namun demikian hasil penelitian ini dapat dijadikan acuan awal bagi peneliti selanjutnya agar lebih baik. Beberapa keterbatasan dan saran dari peneliti adalah sebagai berikut;

Saran bagi anak jalanan. Penulis menganggap penting penelitian ini karena dengan anak jalanan mengetahui dan memahami dirinya sendiri, mereka akan mampu menghasilkan nilai positif dalam mengembangkan konsep dirinya, potensi serta fitrah yang dimiliki, sehingga nantinya kebahagiaan hidup di dunia dan di akhirat dapat dicapai secara optimal. 
Saran bagi pengasuh, orang tua, dan masyarakat. Dalam hal ini, para pengasuh, orang tua, dan masyarakat mempunyai peran penting dalam upaya mengoptimalkan konsep diri serta potensi anak, Karena merekalah panutan bagi anak jalanan. Oleh karena itu para pengasuh, orang tua, dan masyarakat hendaknya memberikan arahan, motivasi, dukungan, baik moral maupun spiritual bagi anak jalanan kaitannya untuk mengembangkan konsep diri, potensi serta fitrah yang dimilikinya, agar dapat berkembang semaksimal mungkin, tentunya demi terlaksananya tugas perkembangan yang sempurna, yaitu menjadi makhluk yang sempurna, baik, mulia, dan seutuhnya, sehingga mereka terhindar dari berbagai tindak penyimpangan dan pelanggaran terhadap nilai-nilai dan aturan yang berlaku di dalam masyarakat maupun agamanya.

\section{Daftar Pustaka}

Arikunto, Suharsimi. 1998. Prosedur Penelitian, Jakarta: Bina Aksara.

Bambang. 1993. Meninos de Ruas dan Kemiskinan, Child Labour Corners News Letter.

Daradjat, Zakiyah. 1983. Kesehatan Mental, Jakarta: CV Gunung Agung.

Dewi, Snorita. 2003. Utang Luar Negeri dan Problem Kemiskinan Negara Berkembang. Global. Vol 8 No 1. Depok. Fisip UI.

Faqih, Aunur Rohim. 2001. Bimbingan dan Konseling Dalam Islam, Yogyakarta : UII Press

Haditono. 2004. Kenakalan Remaja: Suatu Tinjauan Psikologi Perkembangan. Jakarta: Grasindo,

Jumantoro, Totok. 2001. Psikologi Dakwah: Dengan Aspek-Aspek Kejiwaan yang Qur'ani, Amzah.

Kartono, Kartini. 2002. Patologi Sosial I, Jakarta: PT. Raja Grafindo Persada.

Nawawi, Hadari, dkk. 1996. Penelitian Terapan, Yogyakarta: Gadjah Mada University. Press
Nazir, Muhammad. 1988. Metode Penelitian, Jakarta: Ghalia Indonesia.

Odi, Salahudin. 2003. Anak Bukanlah Pemuas Nafsu, Yogyakarta.

Sudarsono. 2005. Kenakalan Remaja, Jakarta: Rineka Cipta.

Supratiknya, A. 1995. Mengenal Perilaku Abnormal, Yogyakarta: Kanisius.

Tasmara, Totok. 2002. Komunikasi Dakwah, Jakarta : Gaya Media Pratama. 
Psympathic, Jurnal Ilmiah Psikologi Juni 2016, Vol. 3, No. 1, Hal: 23 - 34 